\title{
MENDESAIN DAN MENERAPKAN MANAJEMEN STOK (CADANGAN) PANGAN SEBAGAI UPAYA MENINGKATKAN KETAHANAN PANGAN DI DESA PABELAN SUKOHARJO
}

\author{
Imron Rosyadi, dan Noer Sasongko \\ Fakultas Ekonomi Universitas \\ Muhammadiyah Surakarta \\ E-mail: imronkaprawi@yahoo.co.id
}

\begin{abstract}
The problem faced by the village government Pabelan is: (i) What is the 'land of the village treasury managed optimally in supporting the food needs for the people (households) in Pabelan Village?, (ii) Is rice farm in the village that has been done in an efficient Pabelan?, (iii) How is the formulation of government's role model village through 'barn institution (LPD)' village in the management of food reserves in the village Pabelan? And (iv) How is the formulation of models of sustainable management of food reserves to ensure the establishment of food sovereignty (the production, availability and access to food) in the Village Pabelan. In general, the purpose of this activity is to design a management policy of food security (rice) at the village level associated with efforts to optimize the utilization of land and the village treasury LPD strategic role as a buffer stock at the village level. This method is suitable is in the format of coaching and / or community service as well as facilitating forums organized jointly involving the mayor and 12 villages and communities as key stakeholders in the management offood security. Application offood stock management in the village Pabelan expected to have implications for government policy Pabelan significant village, namely: (i) Optimizing the management of 'treasury village land for food (rice) for people (households) in the Village Pabelan, (ii) Efficiency Pabelan rice farm in the village in order to increase income of rice farmers in the village Pabelan, (iii) Strengthening the coordination of management of the stocks (reserves) in the Village Pabelan food through the village barn (LLP), Village, and (iv) The management of food reserves in a sustainable manner so as to ensure the formation offood sovereignty (production, availability and access to food) in the Village Pabelan.
\end{abstract}

Kata kunci: pemrintah desa, ketahanan pangan, manajemen stok pangan

\section{PENDAHULUAN}

\section{Analisis Situasi}

Krisis pangan telah benar-benar terjadi diberbagai belahan dunia. Hal ini ditandai dengan melonjaknya harga-harga pangan dunia seperti makanan pokok berupa gandum, kedelai, beras, dan jagung. Penurunan pasokan berdampak pada harga pangan di pasar dunia semakin melambung, sehingga mengakibatkan masyarakat miskin harus membayar lebih mahal dibandingkan orang kaya di negara maju.

Departemen Pertanian (1999) telah menetapkan isu ketahanan pangan sebagai salah satu fokus utama kebijaksanaan 
operasional pembangunan pertanian dalam Kabinet Gotong Royong (1999-2004), dan komitmen ini dilanjutkan dalam Kabinet Indonesia Bersatu (2004-2009). Memantapkan ketahanan pangan merupakan prioritas utama dalam pembangunan karena pangan merupakan kebutuhan yang paling dasar bagi sumberdaya manusia suatu bangsa.

Sejarah membuktikan bahwa ketahanan pangan sangat erat kaitannya dengan ketahanan sosial, stabilitas ekonomi, stabilitas politik dan keamanan atau ketahanan nasional (Ritonga, 2008; Irianto, 2008). Selain itu, ketahanan pangan dalam arti keterjangkauan pangan juga berkaitan erat dengan upaya peningkatan mutu sumberdaya manusia Indonesia. Tanpa dukungan pangan yang cukup dan bermutu, tidak mungkin dihasilkan sumberdaya manusia yang bermutu, oleh karena itu membangun sistem ketahanan pangan yang kokoh merupakan syarat mutlak bagi pembangunan nasional.

Kejadian rawan pangan dan gizi buruk mempunyai makna politis yang negatif bagi penguasa. Bahkan di beberapa negara berkembang, krisis pangan dapat menjatuhkan pemerintahan yang sedang berkuasa (Ariani et al., 2006). Kejadian rawan pangan di tingkat rumah tangga dengan proporsi cukup besar masih ditemukan di daerahdaerah dengan ketahanan pangan tingkat regional (provinsi) maupun tingkat nasional terjamin (Saliem et al., 2001). Oleh karena itu pencapaian tingkat ketaha-nan pangan yang mantap di tingkat nasional maupun regional saja tidak cukup. Mantapnya ketahanan pangan tingkat desa dan tingkat rumah tangga serta individu merupakan sasaran pembangunan ketahanan pangan suatu Negara.

Pemerintah telah mengeluarkan PP No 68 Tahun 2002 tentang Ketahanan Pangan. Intinya ketahanan pangan sangat penting untuk membentuk manusia Indonesia yang berkualitas, mandiri, dan sejahtera melalui ketersediaan pangan yang cukup, aman, bermutu, bergizi dan beragam serta tersebar merata di seluruh wilayah Indonesia dan terjangkau oleh daya beli masyarakat. Berbekal PP tersebut semestinya, ketahanan pangan menjadi agenda penting bagi pemerintah bersama masyarakat untuk dilaksanakan. Apalagi banyak komoditi penting yang sampai saat ini masih harus impor untuk memenuhi kebutuhan dalam negeri.

Oleh karena itu, membangun kewaspadaan dan atau ketahanan pangan dari strata pemerintahan yang paling rendah yaitu desa (kelurahan) secara bertahap dan konsisten menjadi suatu keniscayaan untuk menjamin tegaknya kedaulatan pangan di tingkat desa dan atau rumah tangga.

Keberadaan lumbung desa yang mempunyai fungsi sosial dan dikelola secara bersama, akan menumbuhkan rasa sosial diantara anggotanya, dan ini merupakan modal sosial pembangunan. Dengan demikian perlu menumbuhkan lumbung desa atau meningkatkan fungsi dan peran-serta dalam meningkatkan ketahanan pangan di desa. Keberadaan lumbung pangan diarahkan menuju lumbung desa sebagai sarana untuk pemupukan cadangan pangan masyarakat yang fungsinya adalah mewujudkan ketersediaan, distribusi dan konsumsi pangan dari waktu ke waktu.

\section{Perumusan Masalah}

Ketahanan pangan merupakan salah satu isu sensitif bagi keamanan suatu bangsa. Secara umum, ketahanan pangan yang rapuh akan memicu terjadinya konflik. Jacques Diouf (2008) selaku Direktur Jenderal Badan Pangan Dunia (FAO), mengatakan bahwa kelangkaan pangan yang disusul melambungnya harga telah memicu kerusuhan, antara lain di Mesir, Kamerun, Haiti dan Burkina Faso.

Ketersediaan pangan yang cukup secara nasional ternyata tidak menjamin 
adanya ketahanan pangan tingkat wilayah (regional), pedesaan, serta rumah tangga individu. Hal ini ditunjukkan antara lain dari studi yang dilakukan oleh Saliem et al. (2004). Terkait dengan fakta tersebut maka masalah bagaimana mengelola ketersediaan pangan yang cukup tersebut agar dapat diakses oleh rumah tangga individu di masing-masing wilayah desa merupakan isu menarik untuk ditelaah. Pengelolaan pangan terkait dengan masalah bagaimana mengelola cadangan pangan, dalam hal ini manajemen cadangan pangan merupakan salah satu aspek yang belum banyak dikaji secara baik.

Desa Pabelan merupakan salah satu desa di wilayah kecamatan kartasura kabupaten Sukoharjo yang mengalami kemajuan pesat dalam pembangunan infrastruktur maupun infrastruktur desa. Desa pabelan memilki wilayah dengan luas 231,9 ha, yang terdiri dari tanah sawah seluas 36,5 ha, tanah kering/tegalan seluas 0,63 ha, tanah pemukiman seluas 163,10 ha dan lahan lain selain tiga kategori tersebut seluas 31, 67 ha. Sebesar $8,66 \%$ dari wilayah (20 ha) merupakan tanah kas desa, yaitu tanah yang semula difungsikan sebagai 'bengkok' ('lungguh') bagi kepala desa dan pamong desa (Pemeritah Desa Pabelan, 2008). Namun mulai periode (2006-2012) pemerintah mengambil kebijakan untuk menyewakan seluruh tanah kas desa kepada petani. Kompensasi atas pemanfaatan tanah kas desa adalah membayar uang sewa kepada pemerintah desa. Hasil sewa tersebut merupakan salah satu sumber pandapatan asli desa (PADes).

Jumlah penduduk pabelan cukup besar yaitu 6.721 orang (1.497 KK), sebagian besar penduduk memiliki pekerjaan sebagai buruh industri yaitu 1.065 orang. Sedangkan yang bekerja di sektor pertanian jauh lebih sedikit yaitu 121 orang dengan rincian 57 orang sebagai petani (memiliki lahan) dan 64 sebagai buruh tani. Namun sumber pendapatan masyarakat terbesar justru diduduki oleh sektor pertanian yaitu dengan pendapatan sebesar 54 juta/tahun, diikuti oleh sektor perdagangan sebesar 30 juta/ pertahun (Pemeritah Desa Pabelan, 2008).

Pada dekade 1994-an, pertumbuhan sektor ekonomi selain pertanian telah berkembang pesat di desa Pabelan, yaitu perdagangan, perindustrian, jasa sosial/ masyarakat, dan jasa dunia usaha. Hal ini ditandai dengan berdirinya supermarket, minimarket, pasar "Bumi Rejo" desa, industri tekstil, pendidikan tinggi, rumah sakit dan pondok pesantren modern di desa Pabelan. Perkembangan pesat sektor ekonomi selain pertanian berdampak pada pergeseran sektor pekerjaan dari pertanian ke sektor industri, perdagangan, dan jasa sosial masyarakat. Sehingga pada akhirnya tenaga kerja di setor pertanian menjadi lebih sedikit, bahkan mengalami kekurangan tenaga kerja. Kedekatan secara geografis, yaitu sebelah timur berbatasan dengan kota Solo, yang merupakan kota perdagangan sedikit-banyak berpengaruh terhadap iklim ekonomi di desa pabelan. Sehingga desa Pabelan sebagai desa pertanian sulit untuk dipertahankan, bahkan mengarah ke desa pemukiman dan perdagangan.

Persoalan-persoalan tersebut jika tidak tangani secara serius, dalam jangka panjang dapat mengarah pada persoalan kerawanan pangan di desa pabelan. Pengelolaan cadangan pangan yang mantap dan berkesinambungan menjadi suatu keniscayaan agar mampu mengatasi kerawanan pangan yang mungkin terjadi di desa pabelan. Sehingga dapat dirumuskan masalah sebagai berikut:

a. Apakah 'tanah kas desa' sudah dikelola secara optimal dalam menunjang kebutuhan pangan bagi masyarakat (rumah tangga) di Desa Pabelan?;

b. Apakah usahatani padi di desa Pabelan sudah dilakukan secara efisien?

c. Bagaimana rumusan model peran pemerintah desa melalui 'Lembaga Lumbung Pangan (LLP)' desa dalam 
pengelolaan stok (cadangan) pangan di desa Pabelan?

d. Bagaimana rumusan model manajemen stok (cadangan) pangan secara berkelanjutan sehingga dapat menjamin tegaknya kedaulatan pangan (produksi, ketersediaan dan akses pangan) di Desa Pabelan.

\section{Tinjauan Pustaka}

a. Konsep Ketahanan Pangan

Konsep ketahanan pangan yang disepakati secara internasional dalam World Conference on Human Right 1993 dan World Food Summit 1996, seperti dilaporkan oleh Saliem et al. (2005); adalah kondisi terpenuhinya kebutuhan gizi setiap individu baik dalam jumlah maupun mutu agar dapat hidup aktif dan sehat secara berkesinambungan sesuai dengan budaya setempat. UndangUndang No.7 tahun 1996 tentang pangan menyebutkan bahwa ketahanan pangan merupakan suatu kondisi terpenuhinya pangan bagi rumah tangga yang tercermin dari tersedianya pangan yang cukup, baik dalam jumlah maupun mutunya, aman, merata dan terjangkau. Rusastra et al. (2005) menyebutkan bahwa ketahanan pangan ditentukan secara bersama antara ketersediaan pangan dan akses individu atau rumah tangga untuk men-dapatkan pangan yang dibutuhkan.

Ariani (2006) melaporkan hasil penelitianya bahwa di Indonesia, peningkatan ketahanan pangan merupakan salah satu program utama nasional sejak satu dasawarsa terakhir. Hal ini juga terkait dengan komitmen Indonesia sebagai salah satu penanda-tangan kesepakatan dalam MDGs yang menegaskan bahwa tahun 2015 setiap negara diharapkan dapat menurunkan kemiskinan dan kelaparan separuh dari kondisi pada tahun 1990. Pada tahun 2004 muncul kembali kasus gizi buruk di Provinsi Nusa Tenggara Timur dan Nusa Tenggara Barat, kemudian diikuti oleh provinsi lainnya. Faktor penyebab kerawanan pangan di suatu wilayah dan rumah tangga mempunyai sifat multidimensional, ditentukan oleh berbagai faktor dan melibatkan berbagai sektor. Mengacu pada karakteristik yang beragam tersebut maka pemecahan masalah kerawanan pangan wilayah dan rumahtangga harus bersifat holistik.

\section{b. Keterjangkauan Pangan \\ Keterjangkauan pangan atau} aksesibilitas masyarakat (rumah tangga) terhadap bahan pangan sangat ditentukan oleh daya beli, dan daya beli ini ditentukan oleh besamya pendapatan dan harga komoditas pangan. Pengaruh pendapatan terhadap akses pangan dapat dilihat melalui pengeluaran bahan pangan, yaitu dengan besamya proporsi pengeluaran rumah tangga untuk bahan pangan. Selanjutnya harga pangan berpengaruh terhadap aksesibilitas terhadap bahan pangan melalui daya beli.

1) Pengeluaran Bahan Pangan. Terdapat hubungan yang negatif antara proporsi pengeluaran bahan pangan dan ketahanan pangan (ditinjau dari akses ke pangan) (Hukum Working 1943, dikutip oleh Pakpahan, dkk., 1993 dalam Rachman, dkk., 2002): (i) Semakin besar proporsi pengeluaran rumah tangga untuk bahan pangan, maka akses terhadap bahan pangan adalah rendah. Semakin besar proporsi pengeluaran rumah tangga untuk bahan pangan juga menunjukkan rendahnya kepemilikan bentuk keka-yaan lain yang dapat ditukarkan dengan bahan pangan; (ii) Semakin 
kecil proporsi pengeluaran rumah tangga untuk bahan pangan, maka akses terhadap bahan pangan adalah besar, atau menunjukkan semakin tinggi ketahanan pangannya. (iii) Semakin kecil proporsi pengeluaran rumah tangga untuk bahan pangan, juga menunjukkan tingginya kepemilikan bentuk kekayaan lain yang dapat ditukarkan dengan bahan pangan; (iv) Rumah tangga tahan pangan yaitu bila proporsi pengeluaran pangan rendah (kurang dari 60 persen dari penge-luaran rumah tangga) dan cukup mengkonsumsi energi (>80 persen dari syarat kecukupan energi); (v) Rumah tangga rentan pangan yaitu bila proporsi pengeluaran pangan tinggi (lebih dari 60 persen dari pengeluaran rumah tangga) dan cukup mengkonsumsi energi (> 80 persen dari syarat kecukupan energi); (vi) Rumah tangga kurang pangan yaitu bila proporsi pengeluaran pangan tinggi (lebih dari 60 persen dari pengeluaran rumah tangga) dan kurang mengkonsumsi energi (:S80 persen dari syarat kecukupan energi) dan (vii) Rumah tangga rawan pangan yaitu bila proporsi pengeluaran pangan tinggi dan tingkat konsumsi energinya kurang. (Milifpk, 2007).

2) Harga Komoditas Pangan. Harga pangan menentukan daya beli masyarakat terhadap pangan, dan terdapat hubungan negatif antara keduanya. Harga yang meningkat (pada pendapatan tetap), maka daya beli menurun, dan sebaliknya apabila harga turun. Dengan demikian stabilitas harga pangan sangat penting untuk menjamin bahwa masyarakat dapat menjangkau kebutuhan pangannya. c. Manajemen Cadangan Pangan

Hasil penelitian Saliem et al. (2004); Saliem et al. (2005) tentang kebijakan pengelolaan cadangan pangan dapat dipaparkan sebagai berikut:

1) Salah satu kekuatan dalam pengembangan cadangan pangan masyarakat adalah tradisi masyarakat petani secara perorangan untuk menyisihkan hasil panennya guna cadangan pangan masih relatif tinggi. Kekuatan lainnya adalah bahwa produksi padi per satuan luas relatif tinggi sehingga memungkinkan masyarakat petani secara perorangan mengalokasikan hasil panennya baik untuk dijual langsung guna mendapatkan uang tunai maupun untuk disimpan sebagai cadangan pangan;

2) Kelemahan pertama dalam pengembangan cadangan masyarakat adalah bahwa pengembangan cadangan pangan oleh rumah tangga petani secara perorangan membutuhkan ruang khusus dengan ukuran tertentu yang dapat digunakan untuk menyimpan gabah hingga menjelang panen berikutnya yang sulit untuk dipenuhi oleh setiap rumah tangga petani. Kelemahan kedua adalah bahwa tradisi masyarakat petani untuk melakukan cadangan pangan secara kolektif dalam bentuk lumbung pangan cenderung melemah;

3) Salah satu faktor yang dapat dipandang sebagai peluang atau kesempatan dalam pengembangan cadangan pangan masyarakat adalah bahwa secara empiris masalah pangan bisa terjadi kapan saja baik disebabkan oleh bencana alam (natural disaster) maupun bencana buatan manusia (konflik sosial) (man made disaster). Faktor lainnya yang dapat dianggap 
sebagai peluang atau kesempatan adalah bahwa pemerintah berkewajiban mendorong keikutsertaan masyarakat dalam penyelenggaraan ketahanan pangan sebagaimana diktum PP Nomor 68 Tahun 2002 tentang Ketahanan Pangan.;

4) Salah satu tantangan atau ancaman dalam pengembangan cadangan masyarakat berupa terciptanya kondisi ekonomi dimana pangan pokok tersedia secara cukup baik jumlah maupun mutunya serta terjangkau daya beli masyarakat seperti terjadi pada paruh kedua jaman Orde Baru. Tantangan atau ancaman lainnya berupa semakin luasnya adopsi kelembagaan sistem panen secara tebasan dengan konsekuensi petani penggarap tidak lagi membawa pulang gabah tetapi uang tunai;

5) Dalam konteks pengembangan cadangan pangan masyarakat, strategi yang dipilih untuk mewujudkan tersebarnya cadangan pangan di semua komponen masyarakat serta teratasinya masalah pangan secara cepat adalah sebagai berikut. Pertama, melakukan sosialisasi bahwa mengandalkan sepenuhnya pemenuhan kebutuhan pangan pokok lewat pasar bebas adalah riskan karena masalah pangan bisa terjadi kapan saja. Kedua, melakukan sosialisasi bahwa petani produsen juga bertanggung jawab untuk menyelenggarakan cadangan pangan masyarakat. Ketiga, menumbuh kembangkan dan sekaligus memelihara tradisi melakukan cadangan pangan di tingkat rumah tangga secara sendiri-sendiri. Keempat, menumbuhkan motivasi petani produsen agar membiasakan diri untuk melakukan cadangan pangan secara kolektif dengan membangun lumbung pangan. Kelima, mengelola lumbung pangan dengan orientasi usaha sebagai kegiatan ekonomi bukan lagi sebagai kegiatan sosial, sehingga lembaga ini secara bertahap dapat berperan sebagai salah satu sarana kegiatan ekonomi masyarakat di pedesaan dan tumbuh kembali tradisi masyarakat petani melakukan cadangan pangan secara kolektif;

6) Dalam konteks pengembangan cadangan pangan pemerintah, strategi yang dipilih untuk mewujudkan tersebarnya cadangan pangan di semua lini pemerintahan serta teratasinya masalah pangan secara cepat adalah sebagai berikut. Pertama, melakukan sosialisasi tentang pentingnya tersedianya cadangan pangan di berbagai tingkat pemerintahan maupun di berbagai elemen masyarakat dalam rangka perencanaan dan pelaksanaan program penanggulangan masalah pangan. Kedua, mempertahankan sistem pencadangan pangan beras yang bersifat sentralistik sebagaimana telah dijalankan selama ini oleh pemerintah pusat. Pertimbangan pertama, dalam implementasinya sistem ini tidak membutuhkan banyak koordinasi sehingga untuk mengatasi masalah pangan yang umumnya harus dilaksanakan dengan segera adalah sangat sesuai. Pertimbangan kedua, penerapan sistem bertingkat dua ( $t w o$ tier system) selama periode tahun 1952-1958 dimana di tingkat pusat dibentuk Yayasan Urusan Bahan Makanan (YUBM) dan di tingkat daerah dibentuk Yayasan Badan 
Pembelian Padi (YBPP) ternyata dalam prakteknya kedua lembaga ini tidak sinkron. Ketiga, melakukan pembagian peran dalam pencadangan pangan antara pemerintah pusat dan pemda berdasarkan pada jenis bahan pangan pokoknya. Keempat, menggunakan pendekatan desentralistik (bukan terpusat) dalam mekanisme penyaluran stok beras untuk keadaan darurat dengan pertimbangan untuk memperpendek jalur birokrasi sehingga penanggulangan masalah pangan dapat dilakukan dengan lebih cepat. Kelima, melakukan pembagian peran dalam pencadangan pangan beras antara pemerintah pusat dan pemda ditinjau dari jenis stok berasnya.

\section{d. Lumbung Pangan Desa}

Kajian terhadap keberadaan lumbung pangan masyarakat oleh Pusat Pengembangan Ketersediaan Pangan dilakukan pada tahun 2002, di propinsi Jawa Barat dan Jawa Tengah. Di Propinsi Jawa Barat, kajian dilakukan di Kabupaten Tasikmalaya, Cirebon dan Cianjur, sedangkan Propinsi Jawa Tengah, di Kabupaten Banyumas, Purworejo, dan Boyolali. Hasil kajiannya sebagai berikut:

1) Modal awal lumbung pangan berbentuk natura yaitu gabah yang disetor sekali pada waktu pembentukan. Selanjutnya tidak ada aktivitas penyimpanan (setor). Aktivitas yang ada adalah peminjaman dan pengembalian dalam bentuk natura. Penggunaan pinjaman untuk konsumsi ada masa paceklik dan bantuan musibah (di Tasikmalaya), selain itu juga untuk modal kerja usahatani (di Cirebon dan Cainjur).
2) Di Jawa Tengah, lumbung desa dianggap sebagai kelembagaan desa yang mendu-kung ketahanan pangan, dimiliki oleh semua desa $(8.530$ desa). Dari sejumlah tersebut, 25,12 persen (2.143 desa) mempunyai lumbung desa secara fisik sebagai temp at menyimpan bahan pangan (padiJ gabah, jagung dan sembako).

3) Kapasitas rata-rata lumbung untuk menyerap marketable surplus relatif kecil dan bervariasi. Kapasitas simp an rata-rata di Jawa Barat adalah 0,59 persen (dengan marketable surplus sekitar 4 juta ton), sedang di Jawa Tengah sebesar 0,92 persen (dengan marketable surplus sekitar 4,5 juta ton GKG).

4) Jasa peminjaman bervariasi antara 030 persen dalam bentuk natura per musim. Penggunaan jasa pinjaman untuk akumu-lasi modal, susut, jasa pengurus dan anggota, serta untuk kegiatan so sial seperti bantuan musibah, pengembangan infrastruktur pedesaan. Ada lumbung desa yang tidak memberikan jasa kepada pengurus.

5) Berdasar hasil kajian tersebut maka keberadaan lumbung desa belum dapat menyerap marketable surplus, sehingga dapat dinyatakan belum dapat digunakan sebagai cadangan pangan masyarakat dan membantu mengamankan harga gabah.

\section{Tujuan dan Manfaat}

Secara umum tujuan kegiatan ini adalah untuk mendesain kebijakan pengelolaan ketahan pangan (beras) di tingkat desa yang dikaitkan dengan upaya mengoptimalkan pemanfaatan tanah kas desa serta peran strategis LLP sebagai buffer stock 
di tingkat desa. Adapun secara rinci tujuan kegiatan ini adalah:

a. Mengoptimalkan 'tanah kas desa' untuk menunjang kebutuhan pangan (beras) bagi masyarakat (rumah tangga) di Desa Pabelan;

b. Meningkatkan efisiensi usahatani padi di Desa Pabelan;

c. Meningkatkan peran pemerintah desa melalui 'lembaga lumbung pangan (LLP)' desa dalam pengelolaan stok (cadangan) pangan di desa Pabelan dan

d. Meningkatkan pengelolaan stok (cadangan) pangan secara berkelanjutan sehingga dapat menjamin tegaknya kedaulatan pangan (produksi, ketersediaan dan akses pangan) di Desa Pabelan.

Diharapkan kegiatan ini memberikan manfaat sebagai berikut:

a. Pengelolaan 'tanah kas desa' menjadi lebih optimal sehingga dapat menunjang kebutuhan pangan (beras) bagi masyarakat (rumah tangga) di Desa Pabelan;

b. Usahatani padi di Desa Pabelan menjadi lebih efisien;

c. Pengelolaan stok (cadangan) pangan di Desa Pabelan menjadi terkoordinasi sistemtis karena adanya lembaga lumbung pangan (LLP) Desa; dan

d. Adanya pengelolaan stok (cadangan) pangan secara berkelanjutan sehingga dapat menjamin tegaknya kedaulatan pangan (produksi, ketersediaan dan akses pangan) di Desa Pabelan.

\section{METODE PELAKSANAAN}

\section{Khalayak Sasaran}

Sasaran utama kegiatan pengabdian ini ditujukan kepada Kepala Desa Pabelan dan 12 perangkat desa, yang terdiri dari: (i) Sekretaris Desa; (ii) Kebayan Wilayah I, II, III, dan IV; (iii) Kaur Pemerintahan; (iv) Kaur Pembangunan; (v) Kaur Keuangan; (vi) Kaur
Kesra; (vii) Kaur Umum; (viii) Jagabaya; dan (ix) Modin.

Sedangkan sasaran antara yang strategis adalah keterlibatan Petani, Pemerintah Desa dan pejabat PEMDA Kabupaten Sukoharjo dalam rangka meningkatkan ketahanan pangan di tingkat Desa.

\section{Realisasi Pemecahan Masalah}

Sebagaimana sudah mafhum bagi masyarakat akademik, bahwa salah satu tugas pokok dosen, yang tertuang dalam Tri Dharma Perguruan Tinggi adalah melaksanaan pengabdian masyarakat. Kegiatan ini merupakan perwujudan dari tugas dosen dalam pengabdian masyarakat. Kegiatan ini akan diselenggarakan atas kerjasama Jurusan Manajemen FE-UMS sebagai institusi penyedia ilmu manajemen terapan dengan Pemerintah Desa Pabelan sebagai subyek pengabdian masyarakat. Kerjasama dalam kegiatan ini bersifat saling menguntungkan, maknanya Pemerintah Desa Pabelan sebagai lembaga pemerintahan yang paling bawah yang secara langsung berhadapan dan melayani masyarakat desa merupakan wahana yang tepat bagi kami ber-empat yang tergabung dalam tim kegiatan ini untuk berkiprah membangun masyarakat pedesaan melalui program-program pemberdayaan masyarakat yang dicanangkan oleh PEMDA Kabupaten Sukoharjo. Disisi lain, Pemerintah Desa Pabelan juga mendapatkan manfaat yang berarti dalam kegiatan pengabdian ini, yaitu adanya sebuah rumusan model manajemen pangan yang bisa diterapkan di Desa Pabelan.

\section{Metode yang Digunakan}

Berdasarkan perumusan masalah dan tujuan yang ingin dicapai dalam pengabdian masyarakat ini, maka metode yang dianggap tepat adalah dalam format pembimbingan dan atau pelayanan masyarakat sekaligus memfasilitasi forum-forum yang diadakan 
secara bersama-sama yang melibatkan Kepala Desa dan 12 perangkat desa-nya serta masyarakat sebagai pelaku utama dalam manajemen ketahan pangan. Forum-forum yang diadakan bersama tersebut untuk membahas dan merumuskan beberapa hal penting menyangkut manajemen ketahanan pangan yaitu: (i) Optimalisasi pemanfaatan 'tanah kas desa'; (ii) merumuskan peran pemerintah desa melalui 'lembaga lumbung pangan (LLP)' desa dalam pengelolaan stok (cadangan) pangan di desa Pabelan; dan (iii) pengelolaan stok (cadangan) pangan secara berkelanjutan sehingga dapat menjamin tegaknya kedaulatan pangan (produksi, ketersediaan dan akses pangan) di Desa Pabelan.

\section{HASIL DAN PEMBAHASAN}

\section{Hasil Kegiatan}

Kegiataan "pelayanan masyarakat dan pembimbingan" dilaksanakan sebulan sekali setiap hari sabtu ke-empat selama empat (4) bulan, sejak bulan Juli - Oktober 2009, bertempat di ruang pertemuan (sidang) yang disediakan oleh pemerintah desa. Sesi pertama, Mengoptimalkan 'tanah kas desa' untuk menunjang kebutuhan pangan (beras) bagi masyarakat (rumah tangga), yang langsung dipandu oleh Ir. Maulidyah Indira H., M.Si. selaku pembimbing utama yang dibantu oleh anggota tim kegiatan. Desain pembimbingan yang dipilih dalam membahas materi ini adalah menggunakan metode ceramah yaitu menyampaikan pokok-pokok pandangan yang dilanjutkan dengan diskusi-interaktif antar-aparatur pemerintah desa, dengan alokasi waktu 60 menit pertama digunakan untuk menyampaikan prinsip-prinsip pengelolaan tanah kas desa dalam rangka meningkatkan ketersediaan beras di desa Pabelan. Selanjutnya 60 menit terakhir digunakan untuk tanya-jawab (diskusi) antara peserta dengan pembimbing utama.
Sesi ke-dua, Meningkatkan efisiensi usahatani padi di Desa Pabelan, yang langsung dipandu oleh Imron Rosyadi, SE, M.Si. yang dibantu oleh anggota tim kegiatan selaku pembimbing utama. Desain pembimbingan yang dipilih dalam menyampaikan materi ini adalah ceramah dan simulasi yaitu menjelaskan tentang bagaimana menghitung tingkat efisiensi usahatani padi yang dilakukan masyarakat Pabelan. Dari hasil perhitungan ini dapat diketahui apakah usahatani padi yang dilakukan oleh masyarakat Pabelan efisien atau tidak? Dengan alokasi waktu 30 menit pertama menjelaskan tentang efisiensi usahatani padi dan bagaimana meningkatkan efisiensi tersebut. Kemudian dilanjutkan dengan diskusi-interaktif dan simulasi yang melibatkan seluruh peserta untuk merumuskan langkah-langkah harus yang dilakukan agar usahatani padi di desa Pabelan mencapai efisiensi.

Sesi ke-tiga, membahas tentang meningkatkan peran pemerintah desa melalui 'lembaga lumbung pangan (LLP)' desa dalam pengelolaan stok (cadangan) pangan di desa Pabelan, yang langsung dipandu oleh Dr. Noer Sasongko, M.Si. selaku pembimbing utama. Desain pengajaran yang dipilih dalam menyampaikan materi ini adalah ceramah, diskusi, dan simulasi. Dengan alokasi waktu, 30 menit pertama menjelaskan tentang peran pemerintah desa dalam pengelolaan stock pangan. Selanjutnya peserta diberi kesempatan untuk bertanya (diskusi) kepada pembimbing dengan alokasi waktu 10 menit. Kemudian 50 menit terakhir dilanjutkan dengan simulasi mendesain manajeman cadangan pangan di desa Pabelan.

Sesi ke-empat, membahas tentang meningkatkan pengelolaan stok (cadangan) pangan secara berkelanjutan sehingga dapat menjamin tegaknya kedaulatan pangan di Desa Pabelan., yang langsung dipandu oleh Fauzan, SE, M.Si selaku instruktur. Desain pembimbingan yang dipilih dalam membahas materi ini adalah menggunakan metode 
ceramah dan diskusi, dengan alokasi waktu 30 menit pertama digunakan untuk menyampaikan materi tentang produksi, ketersediaan dan akses pangan. Selanjutnya 30 menit terakhir digunakan untuk tanya-jawab (diskusi-interaktif) antara peserta dengan instruktur.

\section{Pembahasan}

Keberadaan lumbung pangan atau lumbung desa pernah berperan sangat penting dalam menyangga ketersediaan pangan di desa. Fungsi strategis lumbung desa pada masa lalu dan sekarang adalah:

a. Sebagai cadangan penyediaan pangan;

b. Pada keadaan dimana gagal panen karena adanya hama atau bencana alam, maka keperluan pangan dipenuhi dengan cadangan pangan yang ada di lumbung;

c. Sebagai sarana untuk meningkatkan posisi tawar petani;

d. Pada saat terjadi kelebihan produksi (panen raya) petani dapat mengatur supply-nya dengan menyimpan hasil panennya di lumbung, dan akan dilempar ke pasar pada waktu harga lebih tinggi;

e. Sebagai penyimpan benih. Pada waktu panen, hasilnya disortir, kemudian yang kualitasnya baik disimpan di lumbung sebagai benih dan

f. Mempunyai peran sosial, yaitu salah satunya membantu memenuhi kebutuhan pangan pada masa paceklik.

Penerapan manajemen stock pangan di desa Pabelan diharapkan memiliki implikasi kebijakan bagi pemerintah desa Pabelan yang cukup signifikan, yaitu:

a. Optimalisasi pengelolaan 'tanah kas desa' untuk menunjang kebutuhan pangan (beras) bagi masyarakat (rumah tangga) di Desa Pabelan;

b. Efisiensi usahatani padi di Desa Pabelan dalam rangka meningkatkan pendapatan petani padi di desa Pabelan; c. Pemantapan koordinasi pengelolaan stok (cadangan) pangan di Desa Pabelan melalui lembaga lumbung pangan (LLP) Desa; dan

d. Pengelolaan stok (cadangan) pangan secara berkelanjutan sehingga dapat menjamin tegaknya kedaulatan pangan (produksi, ketersediaan dan akses pangan) di Desa Pabelan.

\section{SIMPULAN DAN SARAN}

\section{Simpulan}

Kegiatan "pelayanan dan pembimbingan masyarakat" yang dilakukan oleh tim pengadian masyarakat dari Fakultas Ekonomi Universitas Muhammadiyah Surakarta terhadap pemerintah dan masyarakat desa Pabelan dapat disimpulkan sebagai berikut:

a. Kegiataan "pelayanan masyarakat dan pembimbingan" dilaksanakan sebulan sekali setiap hari sabtu ke-empat selama empat (4) bulan, sejak bulan Juli Oktober 2009, bertempat di ruang pertemuan (sidang) yang disediakan oleh pemerintah desa;

b. Prosesi pembimbingan dilaksanakan dalam lima sesi pembimbingan (diskusi). Sesi pertama, Mengoptimalkan 'tanah kas desa' untuk menunjang kebutuhan pangan (beras) bagi masyarakat (rumah tangga). Sesi ke-dua, Meningkatkan efisiensi usaha tani padi di Desa Pabelan. Sesi ke-tiga, membahas tentang meningkatkan peran pemerintah desa melalui 'lembaga lumbung pangan (LLP)' desa dalam pengelolaan stok (cadangan) pangan di desa Pabelan. Sesi ke-empat, membahas tentang meningkatkan pengelolaan stok (cadangan) pangan secara berkelanjutan sehingga dapat menjamin tegaknya kedaulatan pangan di Desa Pabelan. 
c. Penerapan manajemen stock pangan di desa Pabelan diharapkan memiliki implikasi kebijakan bagi pemerintah desa Pabelan yang cukup signifikan, yaitu: (i) Optimalisasi pengelolaan 'tanah kas desa' untuk menunjang kebutuhan pangan (beras) bagi masyarakat (rumah tangga) di Desa Pabelan; (ii) Efisiensi usahatani padi di Desa Pabelan dalam rangka meningkatkan pendapatan petani padi di desa Pabelan; (iii) Pemantapan koordinasi pengelolaan stok (cadangan) pangan di Desa Pabelan melalui lembaga lumbung pangan (LLP) Desa; dan (iv) Pengelolaan stok (cadangan) pangan secara berkelanjutan sehingga dapat menjamin tegaknya kedaulatan pangan (produksi, ketersediaan dan akses pangan) di Desa Pabelan.

\section{Saran}

Beberapa saran untuk kegiatan pengabdian berikutnya yang bisa dilakukan di PPMAA terkait dengan penyempurnaan kegiatan ini adalah sebagai berikut:

a. Mengadakan kegiatan pelatihan software (program) komputer yang mendukung pengukuran (penghitungan) efisiensi usahatani padi;

b. Menyelenggarakan kegitan serupa, namum melibatkan seluruh istansi yang terlibat dalam kebijakan ketahanan pangan dari tingkat kecamatan sampai kabupaten;

c. Materi tentang "ketahanan pangan" secara mendalam dimasukkan dalam materi bahasan kegiatan pengabdian berikutnya.

\section{DAFTAR PUSTAKA}

Ariani, M., Saliem H.P., Hardoko G.S. dan Purwantini, T.B., (2006), "Analisis Wilayah Rawan Pangan dan Rawan Gizi Kronis Serta Alternatif Penanggulangannya”. Laporan Akhir Penelitian. PSEKP-Badan Penelitian dan Pengembangan Pertanian, Departemen Pertanian, Jakarta

Basuno, E., Suhaeti, R.N., Budi, G.S., Iqbal, M. dan Suradisastra, K. (2006), "Kaji Tindak (Action Research) Pemberdayaan Masyarakat Pertanian Daerah Tertinggal (Tahap II)", Laporan Akhir Penelitian, PSEKP-Badan Penelitian dan Pengembangan Pertanian, Departemen Pertanian. Jakarta.

Departemen Pertanian (1999). "Ketahanan Pangan dan Kebijaksanaan Operasional Pembangunan Pertanian". Departemen Pertanian, Jakarta.

Griffin, W.G. (2004). “Manajemen”. Penerbit Erlangga. Jakarta.

Ilham, N. (2007). “Analisis profil Petani dan Pertanian Indonesia”. Laporan Akhir Penelitian. PSEKP-Badan Penelitian dan Pengembangan Pertanian. Departemen Pertanian. Jakarta.

Irawan, B., Simatupang, P., Sugiarto, Supadi, Agustin N.K., Sinuraya, J.F. (2006), "Panel Petani Nasional (PATANAS): Analisis Indikator Pembangunan Pertanian dan Pedesaan”. Laporan Akhir Penelitian. PSEKP-Badan Penelitian dan Pengembangan Pertanian. Departemen Pertanian. Jakarta.

Irianto, G. (2008). “Menyelesaikan Konflik Pangan”. Opini Republika. PT Republika Media Mandiri. Jakarta. 
Lakollo, E.M., Rusastra, I.W., Saliem H.P., Supriyati, Friyanto, S., dan Budi, G.S. (2007). "Dinamika Sosial Ekonomi Pedesaan: Analisis Perbandingan Antar Sensus Pertanian". Laporan Akhir Penelitian. PSEKP-Badan Penelitian dan Pengembangan Pertanian Departemen Pertanian. Jakarta.

Mariyono, J. (2006), "Spatial and Temporal Analysis of Technical Efficiency In Indonesian Rice Agriculture With Two Alternative Model Specifications". Jurnal Empirika, 19 (2): 135-153. BPPE Fakultas Ekonomi UMS. Surakarta.

Nurmanaf, A.R., Sugiarto, Julin, A., Supadi, Agustin, N.K., Sinuraya, J.F., dan Zakaria A.K. (2005), "Panel Petani Nasional (PATANAS), Dinamika Sosial Ekonomi Rumah Tangga dan Masyarakat Pedesaan: Analisis Profitabilitas Usahatani dan Dinamika Harga dan Upah Pertanian”. Laporan Akhir Penelitian. PSEKP-Badan Penelitian dan Pengembangan Pertanian. Departemen, Pertanian. Jakarta.

Pemerintah Desa Pabelan (2008), "Laporan Tahunan Kades". Un-Published

Pemerintah Desa Pabelan (2008), "Daftar Isian dalam Rangka Perlombaan desa". Un-Published

Sayaka, B., Ariani M., Siregar M., Supriadi, H., Ariningsih, E., Rahmanto, B., Asikin, A. (2005). "Analisis Pengembangan Agroindustri Berbasis Pangan Lokal Dalam Meningkatkan Keanekaragaman Pangan dan Pengembangan Ekonomi Pedesaan”. Laporan Akhir Penelitian. PSEKP-Badan Penelitian dan Pengembangan Pertanian Departemen Pertanian. Jakarta.

Saliem, H.P., Purwoto, A., Hardono, G.S., Purwantini, T.B., Supriyatna, Y., Marisa, Y. dan Waluyo (2005). "Manajemen Ketahanan Pangan Era Otonomi Daerah dan Perum Bulog". PSEKP-Badan Penelitian dan Pengembangan Pertanian, Departemen Pertanian. Jakarta.

Ritonga, R. (2008). "Bukan Sekedar Ketahanan Pangan”. Opini Republika. PT Republika Media Mandiri. Jakarta.

Rusastra I.W., Noekman K.M., Supriyati, Erma, S., Elizabeth, R., dan Suryadi, M., (2005), "Analisis Ekonomi Ketenagakerjaan Sektor Pertanian dan Pedesaan di Indonesia". PSEKP-Badan Penelitian dan Pengembangan Pertanian, Departemen Pertanian. Jakarta. 